\title{
T-tubule biogenesis and triad formation in skeletal muscle and implication in human diseases
}

Lama Al-Qusairi ${ }^{1,2,3,4,5,6}$ and Jocelyn Laporte $1,2,3,4,5^{*}$

\begin{abstract}
In skeletal muscle, the excitation-contraction (EC) coupling machinery mediates the translation of the action potential transmitted by the nerve into intracellular calcium release and muscle contraction. EC coupling requires a highly specialized membranous structure, the triad, composed of a central T-tubule surrounded by two terminal cisternae from the sarcoplasmic reticulum. While several proteins located on these structures have been identified, mechanisms governing T-tubule biogenesis and triad formation remain largely unknown. Here, we provide a description of triad structure and plasticity and review the role of proteins that have been linked to T-tubule biogenesis and triad formation and/or maintenance specifically in skeletal muscle: caveolin 3, amphiphysin 2, dysferlin, mitsugumins, junctophilins, myotubularin, ryanodine receptor, and dihydhropyridine Receptor. The importance of these proteins in triad biogenesis and subsequently in muscle contraction is sustained by studies on animal models and by the direct implication of most of these proteins in human myopathies.
\end{abstract}

\section{Introduction}

To trigger skeletal muscle contraction, the action potential generated by motor neurons is transmitted through motor nerves to muscle cells. The excitation-contraction (EC) coupling, i.e. signal transmission from the sarcolemma to the actin/myosin apparatus, is mediated by a second messenger, calcium ions. Indeed, muscle fibers contain large internal calcium stores with the ability to quickly release and retrieve calcium (Figure 1, right panel). For a fast and fine-tuning of muscle contraction, these stores are maintained under the control of the action potential, which ensures calcium release simultaneously within the whole interior of the muscle fiber. As myofibers are 50-100 $\mu \mathrm{m}$ in diameter and several millimeters to centimeters long, a highly specialized structure named the triad is necessary to overcome spatial limits in using calcium as secondary messenger, and connect the sarcolemma with the calcium stores. The sarcolemma forms regular invaginations which insert between myofibrils, termed transverse tubules ( $\mathrm{T}$ -

\footnotetext{
* Correspondence: jocelyn@igbmc.fr

'Department of Translational Medecine and Neurogenetics, IGBMC (Institut de Génétique et de Biologie Moléculaire et Cellulaire), 1 rue Laurent Fries, 67404 Illkirch, France

Full list of author information is available at the end of the article
}

tubules). In skeletal muscle, T-tubules tightly associate with the sarcoplasmic reticulum (SR), in a region called terminal cisternae/junctional SR. The close association of one T-tubule with two terminal cisternae on both sides of the tubule forms the triad (Figure 1).

A large set of specialized proteins takes part in EC coupling and includes: i) the Dihydhropyridine Receptor (DHPR), a voltage gated calcium channel located on Ttubule membranes [1,2], ii) the Ryanodine Receptor (RyR1), a calcium release channel that is localized on the junctional face of SR and appears as "feet" when observed by electron microscopy (Figure 1, left panel) [3], iii) calcium buffering proteins such as calsequestrin in the lumen of the SR [4], iv) calcium channel regulators such as calmodulin, FKBP12 and many others [5,6], v) Sarco-Endoplasmic Reticulum Calcium ATPase pumps (SERCA), which is indirectly involved in EC coupling via its action in the rapid removal of the cytosolic calcium after fiber shortening to replenish the calcium stores [7]. Noteworthy, the physical coupling between RyR1 and DHPR occurs specifically in skeletal but not in cardiac muscles and allows the transmission of the signal within $2 \mathrm{~ms}$ in skeletal muscles compared to 100 $\mathrm{ms}$ in cardiac muscles [8]. In cardiac myofiber, RyR2mediated calcium release is induced by extracellular 


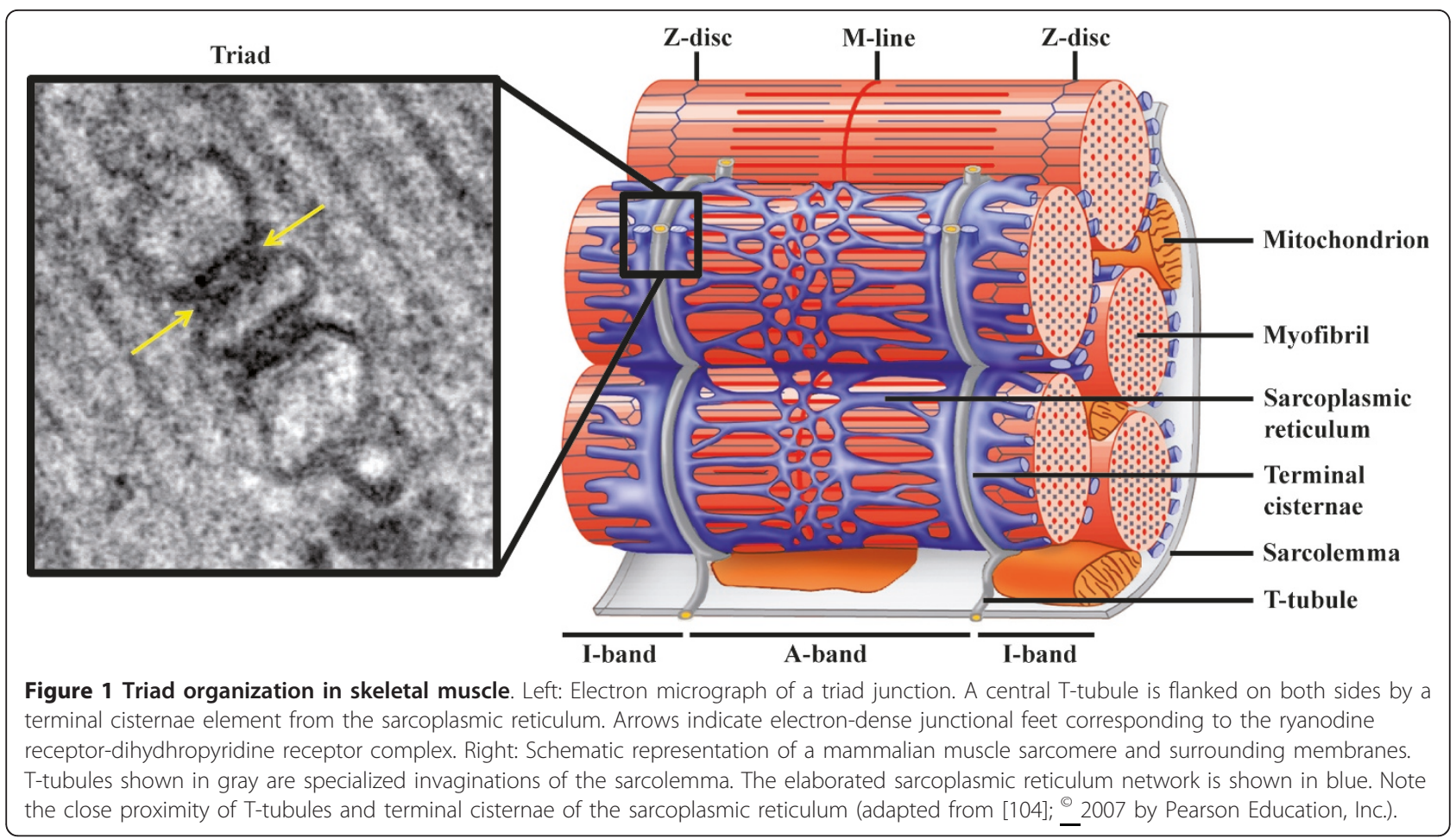

calcium entry via DHPR in a mechanism called calciuminduced calcium release (CICR) [8]. Moreover, in fibers of small diameter, such as the body muscles of Amphioxus, peripheral couplings between SR and the plasmalemma have similar function to triads. In addition, all differentiating muscle fibers pass through a stage where $\mathrm{T}$-tubules are not present and EC coupling is mediated by such peripheral couplings.

In this review, we will focus on the molecular mechanisms underlying $\mathrm{T}$-tubules biogenesis and triad formation specifically in skeletal muscle. Triad defects linked to human monogenic diseases will also be highlighted.

\section{T-tubule plasticity}

The T-tubule membrane possesses a high plasticity which provides the stability required during muscle contraction, and facilitates repair upon damage. In addition to its principal function in EC coupling, the plasticity of T-tubules confers to this system non-related EC functions.

It has been reported that the treatment of isolated muscle fibers with glycerol efflux-influx or with other low molecular weight nonelectrolytes (such as sugars) physically affects T-tubules morphology. Such osmotic shock can convert the T-tubule network into many membrane-bound vacuoles, which can either remain interconnected by normal T-tubules, or become separated (Figure 2) $[9,10]$. Surprisingly, this vacuolation which results in 5-15 fold increase in the relative volume of $\mathrm{T}$-tubule system is reversed spontaneously $[11,12]$. Moreover, this observation is specific to transverse tubule membranes, as no other intracellular membrane systems appear to be involved [12], probably due to the fact that their lumen connects to the extracellular space.

In addition to this artificial condition, this vacuolation phenomenon is observed upon muscle fatigue or diseases $[10,13]$. Based on this plasticity and on the large membrane surface of the T-tubules network which corresponds to about $80 \%$ of the sarcolemma surface, several functions non-related to EC coupling are proposed for the T-tubules system $[10,13]$. These include: i) water balance and regulation of cell volume, ii) recovery from muscle fatigue, iii) transport pathways including endocytosis, exocytosis and the penetration of foreign DNA. The molecular mechanisms involved in these processes are still to be investigated.

\section{Morphological aspects of triad biogenesis Sarcoplasmic reticulum}

The SR represents the main calcium store in striated muscle. It is highly specialized to ensure the simultaneous release of intracellular calcium in the entire cytosol of the muscle cell. The first step of SR biogenesis starts by the formation of tubular endoplasmic reticulum (ER) (30-60 nm in diameter) adjacent to the myofibril [14]. Subsequently, these tubular branches of ER 


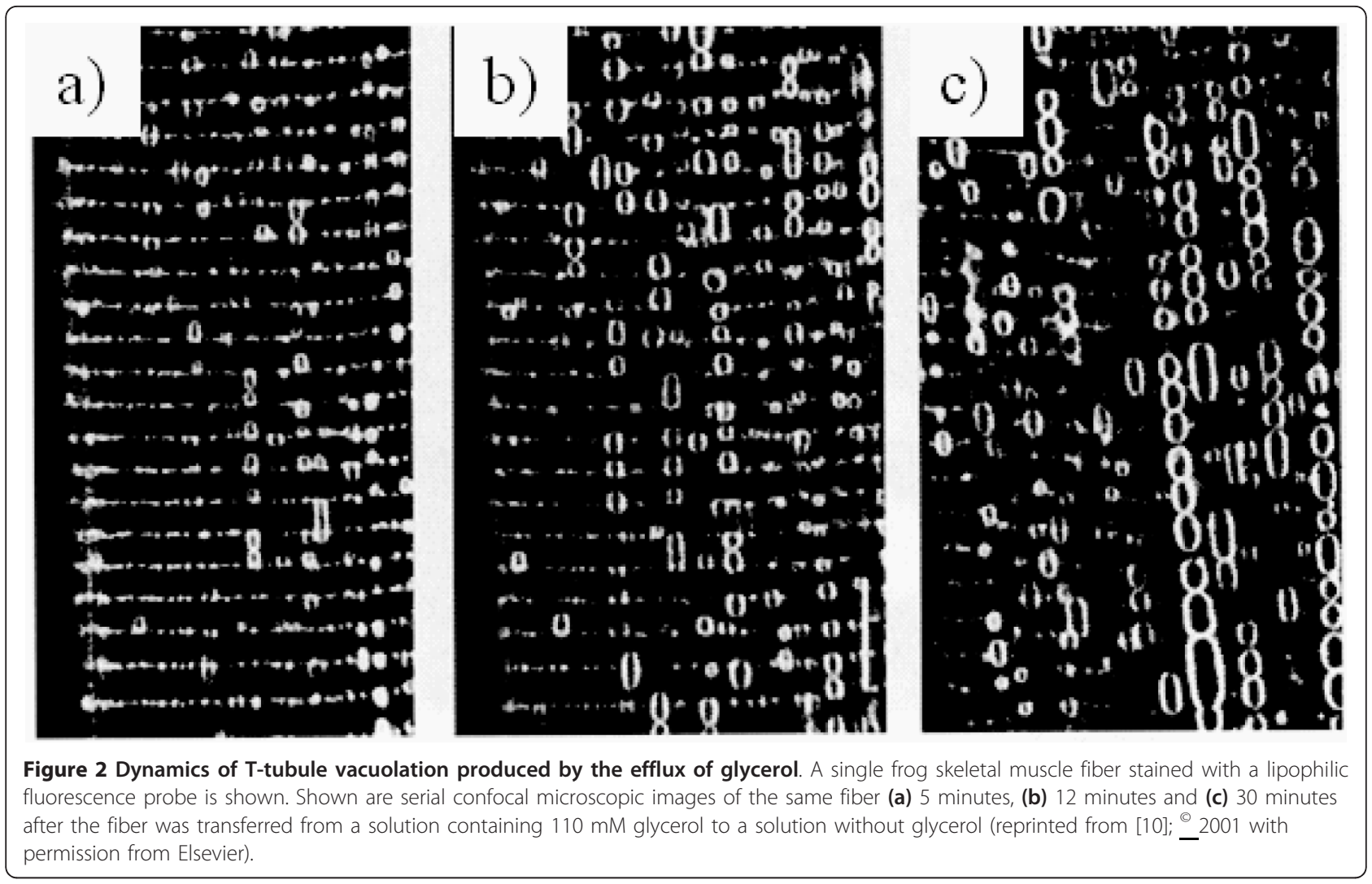

develop into reticular structures surrounding the myofibrils [15]. Finally, the newly formed SR engages couplings at the A-I interface with the T-tubule originating from the sarcolemma. The molecular determinants implicated in the functional and structural organization of the SR have been reviewed elsewhere [16].

The chronology of SR biogenesis was well investigated using electron microscopy (EM) during muscle differentiation in mouse [17]. These observations were also supported by studies employing chicken embryo [18]. In mouse, the SR is detected from as early as embryonic day 14 (E14) with punctate RyR clusters that are located in the periphery of the myofiber [17]. At this stage, the content of the feet (RyR) in the junctional SR is poor, and some SR elements without any feet are observed. At E16, RyR containing elements become abundant and start to be associated with the edges of A bands (A-I junctions) of the newly formed sarcomeres. This association results in a distinct banding pattern of a discrete SR network at the I-band with thin longitudinal connecting SR elements [17]. During the next days (E17 and E18), junctional SR acquires a predominant transverse distribution taking their final position by forming triad rows at each side of the Z-line (two SR sacs connecting one T-tubule in each triad) [17]. During the maturation of SR membranes, the frequency of feet increases, in particular, between E16 and E18, when all junctions become filled by feet. The width of the junctional gap is between 9 and $12 \mathrm{~nm}$. The maturation of the RyR containing elements is accomplished at birth [17]. Elegant experiments using tagged SR proteins in differentiating myotubes showed that the SR organization was paralleled by a dynamic localization of longitudinal and junctional SR proteins [19].

\section{Transverse tubule}

$\mathrm{T}$-tubules are invaginations of the plasma membrane, which are present exclusively in striated muscle. Their role is to maintain the SR calcium store under the tight control of membrane depolarization via the voltage sensor channel DHPR [2]. Morphological studies in chicken and mouse embryos have revealed that the T-tubules start their formation after the SR $[17,18]$. In mouse embryos, the first defined tubules can be observed at E15. At this stage they take the aspect of short cylinders invaginating from the sarcolemma within the myotubes [17]. At E16, the newly formed T-tubules extend deeper within the myofiber, maintaining a connection with the surface by short transverse segments however they stay predominantly longitudinal. During the last days of gestation (E17, 18, 19), T-tubules progressively invade the entire fiber; the majority of them are longitudinal with some transverse connecting elements $[17,18]$. The 
transverse orientation of T-tubules is achieved during the postnatal period. Final maturation of T-tubules is completed in mouse 3 weeks after birth $[17,20]$.

\section{Molecular mechanisms involved in T-tubule biogenesis and triad formation and maintenance}

Although the events characterizing T-tubule biogenesis and triad formation are morphologically defined, molecular mechanisms remain elusive. In the last 20 years, several proteins were proposed to be involved in these mechanisms, and mutations within most of the corresponding genes are associated to muscular disorders in human and/or in rodents. These proteins include caveolin 3 (CAV3), the skeletal muscle specific isoform of amphiphysin 2 (BIN1), dysferlin (DYSF), mitsugumins (MG), junctophilin (JPH1), and myotubularin (MTM1) (Table 1). In this context, one should distinguish between mechanisms leading to $\mathrm{T}$-tubule biogenesis and those involved in the proper assembling of triad components (i.e. one T-tubule element with two junctional SR cisternae). Based on previous reports, we classified CAV3, BIN1, DYSF in T-tubule biogenesis, and mitsugumins and junctophilin in triad formation, while the position of MTM1 in this classification is still unclear.

\section{Caveolin 3}

Caveolae are subcompartments of the plasma membrane which take the aspect of 50-100 nm vesicular invaginations, and have an important role in signal transduction and vesicular transport [21]. In contrast to the other plasma membrane regions which are composed mainly of phospholipids, caveolae are considered as cholesterolsphingolipid rich raft domains [22]. The principal protein components of the caveolae are the caveolins (CAV), which are cholesterol-binding proteins [22]. The caveolin family is represented in mammals by three members; both CAV1 and CAV2 are co-expressed in non-muscle cells especially adipocytes [21,23] whereas CAV3 is found essentially in striated muscles, and its expression is induced during muscle differentiation [24]. In skeletal muscle, CAV3 localizes at the sarcolemma where it can form a complex with dystrophin and its associated glycoproteins [25]. In addition to the sarcolemma, CAV3 is localized to the developing T-tubules [26].

Mutations within $C A V 3$ are associated with several muscular disorders. In particular, mutations which lead to loss of the CAV3 protein, or a decrease of more than 90\% of CAV3 expression, result in autosomal dominant limb-girdle muscular dystrophy (LGMD1C), manifesting by mild to moderate proximal muscle weakness [27]. In addition, $C A V 3$ is found mutated in rippling muscle disease [28], familial hypertrophic cardiomyopathy [29] and long QT syndrome 9 [30]. Moreover, its expression is increased in tibialis anterior from the $\mathrm{mdx}$ mouse, suggesting that CAV3 may contribute to the pathogenesis of DMD [31].

Mice lacking CAV3 display a mild myopathic phenotype similar to the human pathology [32]. Besides, the ectopic expression of CAV3 in mice leads to Duchennelike muscular dystrophic phenotype [33]. According to its localization at T-tubules, CAV3 deletion leads to disorganization of $\mathrm{T}$-tubule membranes which become dilated and lose their transverse orientation (Figure 3a and $3 b)$ [32]. This provides evidence that CAV3 is crucial for muscle function and has a role in T-tubules biogenesis. Several evidences lead to the hypothesis that similar mechanisms control the formation of the $\mathrm{T}$ tubule system and the caveolae. Indeed, the mature and the developing T-tubules are associated with CAV3 and contain approximately four times more cholesterol than the plasma membrane [34,35]. Moreover, treatment of epithelial cells with Amphotericin B, a cholesterol-binding drug, results in a loss of morphologically defined caveolae at the cell surface. Similarly to CAV1 in epithelial cells, DHPR $\alpha$ and CAV3 are dramatically redistributed after Amphotericin B treatment of $\mathrm{C} 2 \mathrm{C} 12$

Table 1 Proteins implicated in triad organization, roles and associated human diseases ${ }^{a}$

\begin{tabular}{|c|c|c|c|c|c|c|c|}
\hline \multirow[b]{2}{*}{ Proteins } & \multicolumn{2}{|c|}{ Phenotype in humans } & \multicolumn{2}{|c|}{ Phenotype in rodents } & \multirow[b]{2}{*}{ Membrane binding } & \multirow[b]{2}{*}{ Membrane events } & \multirow[b]{2}{*}{$\begin{array}{l}\text { Associated human } \\
\text { diseases }\end{array}$} \\
\hline & $\begin{array}{l}\text { Skeletal } \\
\text { muscle }\end{array}$ & $\begin{array}{l}\text { Cardiac } \\
\text { muscle }\end{array}$ & $\begin{array}{l}\text { Skeletal } \\
\text { muscle }\end{array}$ & $\begin{array}{l}\text { Cardiac } \\
\text { muscle }\end{array}$ & & & \\
\hline CAV3 & Yes & Yes & Yes & Yes & Cholesterol binding & Caveolae formation & $\begin{array}{l}\text { LGMD-1C, RMD, FHC, } \\
\text { LQTS }\end{array}$ \\
\hline BIN1 & Yes & Yes & n.r. & Yes & Phosphoinositide binding & Membrane tubulation & ARCNM \\
\hline DYSF & Yes & Yes & Yes & Yes & $\begin{array}{l}\text { Transmembrane/ } \\
\text { phospholipid binding }\end{array}$ & Membrane repair & Dysferlinopathies \\
\hline MG29 & n.r. & n.r. & Yes & No & Transmembrane binding & Triad structure & n.r. \\
\hline $\mathrm{JPH1}$ & n.r. & n.r. & Yes & No & Phospholipid binding & $\begin{array}{l}\text { Sarcolemma and SR junction } \\
\text { formation }\end{array}$ & n.r. \\
\hline MTM1 & Yes & No & Yes & No & Phosphoinositide binding & Membrane transport & XLMTM (XLCNM) \\
\hline
\end{tabular}

${ }^{a}$ n.r., not reported; LGMD-1C, limb-girdle muscular dystrophy type $1 \mathrm{C} ; \mathrm{RMD}$, rippling muscle disease; FHC, familial hypertrophic cardiomyopathy; LQTS, long-QT syndrome; ARCNM, autosomal recessive centronuclear myopathy; SR, sarcoplasmic reticulum; XLMTM, X-linked myotubular myopathy; XLCNM, X-linked centronuclear myopathy. 


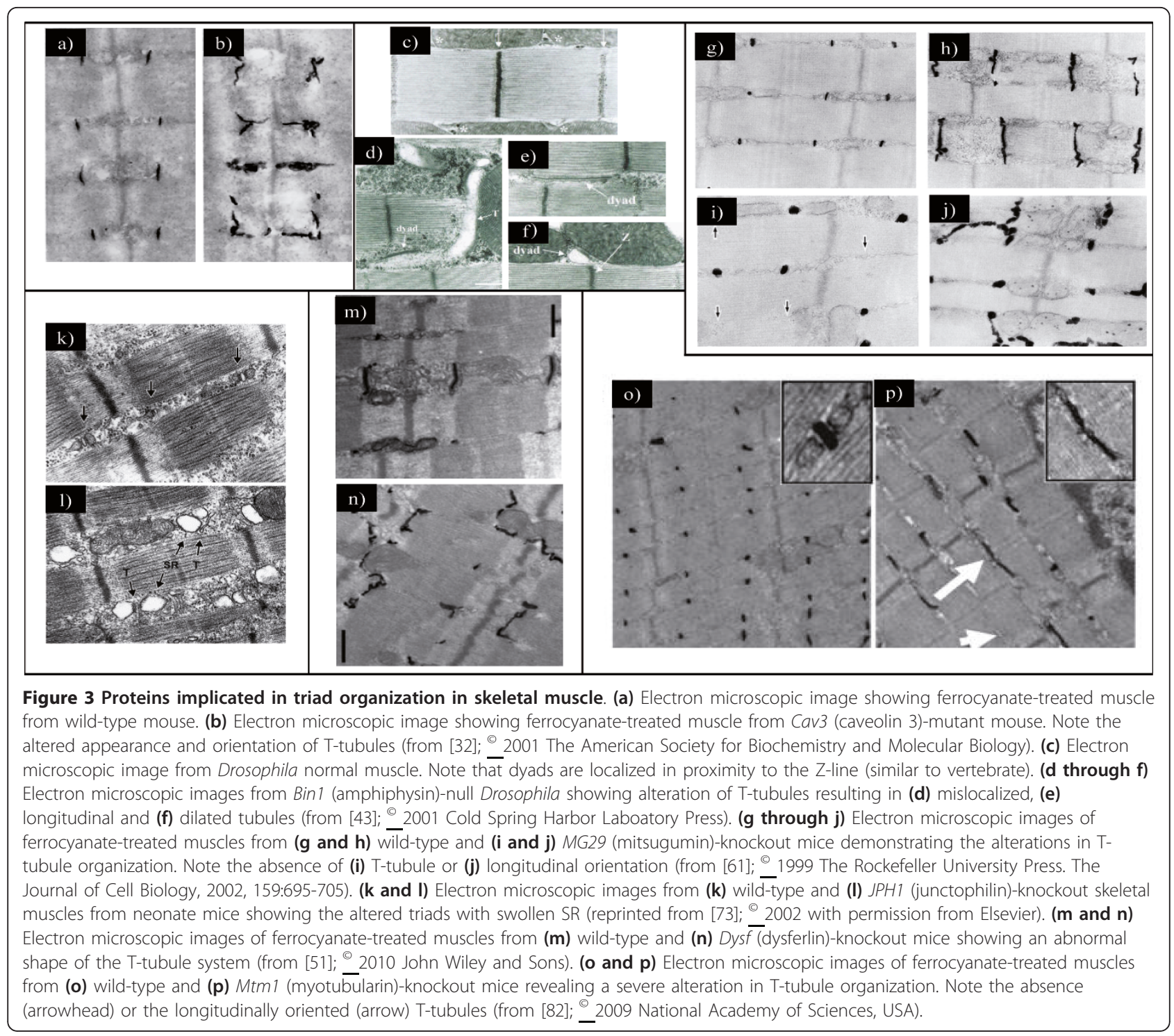

myotubes. Interestingly, other cholesterol-rich compartments such as the trans-Golgi network do not seem affected [34].

\section{Amphiphysin 2 (BIN1)}

Mutations in BIN1 are associated to the autosomal recessive form of centronuclear myopathy [36], a disease characterized by muscle weakness, myofiber atrophy, and abnormal positioning of nuclei within muscle fibers.

Amphiphysins are membrane bending and curvature sensing proteins able to tubulate lipid membranes via their BAR (Bin/Amphiphysin/Rvs) domain. The ubiquitous amphiphysin 2, encoded by the BIN1 gene, is highly expressed in skeletal muscle and is proposed to participate in T-tubule biogenesis. Its role in this process is provided by a polybasic amino-acid stretch encoded by exon 11, which is important for its recruitment to T-tubule membranes $[37,38]$. This polybasic sequence can bind specifically the phosphoinositides PtdIns $(4,5) P_{2}$ and PtdIns4P in vitro. Interestingly, the levels of PtdIns $(4,5) P_{2}$ and BIN1 increase simultaneously during C2C12 myotubes differentiation [37,39].

In addition, BIN1 can tubulate membranes separately or in cooperation with dynamin 2 (DNM2), another protein mutated in centronuclear myopathy [40,41]. The cooperation between BIN1 and DNM2 is mediated by the interaction of BIN1 SH3 domain with the proline rich domain of DNM2. However, this interaction may not occur prior to BIN1 association to membranes, as the polybasic sequence binds to the $\mathrm{SH} 3$ domain when it is not membrane bound [42]. Indeed, PtdIns $(4,5) P_{2}$ binding is necessary to release the $\mathrm{SH} 3$ domain, further enabling the interaction between the $\mathrm{SH} 3$ domain and DNM2 [42]. While the existence of this intramolecular regulation has been deciphered in cultured cells, it is 
not determined whether a similar mechanism regulates T-tubules curvature. Nevertheless, myotubes expressing a BIN1 mutant lacking the polybasic sequence failed to form a normal membrane tubules network [42].

A drosophila mutant lacking the orthologue of BIN1 (amphiphysin) exhibits a skeletal muscle defect associated to alterations in T-tubule morphology and EC coupling (Figure 3c-f) [43]. Interestingly, EM analysis of muscle biopsies from patients with BIN1 mutations revealed abnormal morphology of T-tubules [44]. In cultured COS-1 cells, overexpression of a mutation related to $\mathrm{CNM}$ in the BAR domain failed to form membrane tubules compared to the wild-type construct, suggesting that the lack of BIN1-mediated membrane remodeling could be at the basis of the muscle disease [36].

Surprisingly, no skeletal muscle defect was reported in Bin $1^{-/-}$mice. However, these mice are dying perinatally due to cardiomyopathy, precluding a detailed analysis of skeletal muscle after birth [45].

\section{Dysferlin}

Dysferlin (DYSF) is a $230 \mathrm{kDa}$ protein belonging to a family of genes similar to Caenorhabditis elegans ferlin. It contains a C-terminal transmembrane domain and multiple $\mathrm{C} 2$ domains implicated in calcium binding and calcium-dependent membrane fusion and repair. Mutations within the DYSF gene are associated with allelic muscular disorders including autosomal recessive limbgirdle muscular dystrophy type 2B [46], Miyoshi myopathy [47], and distal anterior compartment myopathy [48]. DYSF has a sarcolemmal localization in differentiated skeletal muscle, which is related to its role in membrane repair [49]. However, studies performed in C2C12 cells have shown that during myotubes differentiation, DYSF is associated to the T-tubules network in addition to sites of cells fusion, and can translocate to the sarcolemma upon myofiber injury [50]. Interestingly, studies performed in adult rat muscles, in which regeneration was induced by subcutaneous injection of notexin, have revealed that during early stage of muscle fiber regeneration (within the first week after notexin treatment), DYSF is mainly localized to T-tubules and translocates toward the sarcolemma in later stages of regeneration [51].

Several mouse lines have been generated to manipulate the level and the function of DYSF, and the spontaneous SJL strain was shown to encompass an in-frame deletion in the C-terminal of the Dysf gene [49,52-55]. Similarly to CAV3 mouse mutants, mice deficient for DYSF display alterations in T-tubule structure, with more dilated and longitudinally oriented tubules [51] (Figure $3 \mathrm{~m}-\mathrm{n}$ ). These defects are considered as primary, as they are observed at early stage of the disease when abnormalities in the myofibrillar architecture and the sarcolemma are minimal. The role of DYSF in T-tubule biogenesis is still not determined, however, it has been suggested that DYSF contributes to the fusion of caveolin 3 containing vesicles with T-tubules. This suggestion is based on i) the interaction of DYSF with DHPR in mature skeletal muscle, ii) the known interaction between DYSF and CAV3, and iii) the partial co-localization between CAV3 and DYSF during early myogenesis $[56,57]$. This hypothesis is also supported by the accumulation of subsarcolemmal vacuoles contiguous with the T-tubule system in dysferlinopathy patients [58].

\section{Mitsugumins}

In addition to the proteins mentioned above, which are involved in the biogenesis of T-tubules, other proteins are implicated in the maturation of SR terminal cisternae, and the junction between T-tubules and SR. This is the case of members of the Synaptophysin family such as mitsugumin 29 (MG29 or synaptophysin-like 2, SYPL2), a transmembrane proteins highly enriched in heavy SR vesicles preparation [59]. MG29 is expressed early during myogenesis, even before the apparition of triads. It first associates to newly formed SR vesicles and then to triads, which appear later during myogenesis [59]. These observations implicate MG29 in the early formation of junctional SR and its connection to Ttubules $[59,60]$. In MG29-KO mice, decreased muscle mass and a slight decrease in the force generation capacity were observed [61]. Dysfunction of store-operated calcium entry (SOCE) leading to defects in intracellular calcium homeostasis, and increased muscle fatigability were also reported in these mice [62,63]. EM analysis of mutant muscles revealed morphological alterations in triad structures, including a swollen SR and longitudinal T-tubules (Figure 3g-j) [61]. However, the actual association between SR and T-tubules does not appear altered. It thus remains unclear whether such disorders in the triad structure have a link with the observed defect in SOCE.

Another mitsugumin, MG53 (also called TRIM72), has been identified as a key player in intracellular membrane trafficking and membrane repair machinery in striated muscles $[64,65]$. In addition to it specific expression in striated muscles, MG53 was shown to bind to dysferlin and caveolin 3, two proteins directly implicated in Ttubule biogenesis $[64,66]$. There are no studies demonstrating a direct implication of MG53 in the biogenesis of triad membranes; however, the current evidences sustain its implication as a potential new partner in this mechanism.

\section{Junctophilins}

JPH family members are identified as components of junctional membranes, where they may bridge the SR via their $\mathrm{C}$-terminal transmembrane domain, with the $\mathrm{T}$-tubule/plasma membrane via their $\mathrm{N}$-terminal 
domain. More specifically, the N-terminal domain can bind to membrane phospholipids including sphingomyelin and phosphatidylcholine [67]. Among the four junctophilin-like proteins in mammals (JPH1-4), JPH1 is expressed mainly in skeletal muscle while JPH2 is also expressed in cardiac muscle and implicated in hypertrophic cardiomyopathies [67-69]. However, JPH3 and 4 are coexpressed in brain where JPH3 is found to be associated to a Huntington-like disease [70,71].

JPH1 deficient mice die shortly after birth due to defects in jaw muscles resulting in lack of milk suckling [72]. Electron microscopy analysis of skeletal muscle from embryos and newborn mice revealed several abnormalities in triad morphology, leading to defect in muscle contraction [72,73]. These anomalies include a reduced number of triads, swollen junctional SR, partially vacuolated longitudinal SR and irregular orientation of SR network (Figure 3k-1). Moreover, functional analysis of mutant muscles from neonate mice revealed that these muscles have an increased response to extracellular calcium stimuli, indicating a defect in EC coupling [72]. A specific role of JPH1 in the biogenesis of membrane junctions is also supported by its ability to induce junctions between the endoplasmic reticulum and the plasma membrane when overexpressed in amphibian embryonic cells [67]. In addition, the expression of JPH1 is enhanced after birth as an indicator of a role in the late biogenesis and maturation of triads [72].

\section{Myotubularin}

Myotubularin (MTM1) is part of a family of phosphoinositides phosphatases conserved through evolution down to yeast, and with 14 members in human [74]. While myotubularin is ubiquitously expressed, mutations within MTM1 lead to a skeletal muscle disorder: the X-linked form of centronuclear myopathy, also called myotubular myopathy, associating severe muscle atrophy and weakness at birth with abnormal positioning of nuclei [75]. This indicates that MTM1 has a muscle-specific role, which cannot be compensated by homologous proteins. In vitro and overexpression studies performed in yeast and mammalian cells have attributed to MTM1 a function in endosomal and membrane trafficking pathways and have shown that MTM1 specifically dephosphorylates PtdIns $3 P$ and PtdInsp $(3,5)$ $P_{2}$ into phosphatidylinositol and PtdIns5P respectively [76-79]. Recently, immunohistology and EM analysis revealed that AAV mediated overexpression of MTM1 in mouse muscle results in the formation of abnormal membrane structures [80]. These structures include vacuoles that are derived from sarcolemma and/or $\mathrm{T}$ tubules, as they have positive staining for caveolin-3, dystrophin and dihydropyridine receptor (DHPR), and negative staining for laminin 2 , and also contain the exogenous MTM1 protein [80]. This indicates a direct or indirect role for MTM1 in the generation or maintenance of membrane structures in skeletal muscle.

Mtm1 KO mice exhibit a progressive centronuclear myopathy [81]. EM analysis of Mtm1 KO muscles revealed alterations in T-tubules structure characterized by longitudinal orientation of $\mathrm{T}$-tubules and the presence of triads deprived from $\mathrm{T}$-tubule components (Figure 3o-p) [82]. These alterations become more pronounced with disease progression $[44,82]$. Similarly, $m t m 1$ zebrafish morphants and $m t m$-depleted drosophila muscles display structural defects of the triads, and such defects have been also observed in muscles from patients with myotubular myopathy $[44,83,84]$. Since MTM1 expression is increased in the postnatal life in mouse and Mtm1 KO muscles display less altered T-tubules at an early stage than at a late stage of the disease, it is likely that MTM1 plays a key role in the late maturation and/or the maintenance of $\mathrm{T}$-tubules rather than in their early biogenesis.

\section{The RyR-DHPR complex}

The RyR-DHPR interaction is physically linking the SR to T-tubules in skeletal muscle, and thus mediates the translation of the action potential into intracellular calcium release. RyR1, the skeletal muscle ryanodine receptor, is implicated in the susceptibility to malignant hyperthermia [85,86], and mutated in myopathies with variable histological outcomes as central core $[87,88]$, multi-minicore [89], congenital fiber type disproportion $[90,91]$, and/or nuclei centralization $[92,93]$. It was thought that the direct interaction between RyR and DHPR is necessary for T-tubule and SR assembly [94]. The concomitant expression of RyR and DHPR during myogenesis is consistent with this idea [94]. However, it has been shown by immunofluorescence and EM studies performed in mouse models lacking one or both proteins that it is unlikely to be the case. More specifically, mutant mice lacking RyR (dyspedic) or DHPR (muscular dysgenesis, mdg mouse), or even both proteins form triadic junctions with a similar architecture than wildtype mice [95-99]. Moreover, these myotubes have a normal disposition of other SR components such as calsequestrin and triadin, although calcium release from intracellular stores is greatly affected $[96,100]$. This indicates that neither RyR nor DHPR are necessary for the biogenesis of the triad structure.

In addition, the targeting of DHPR and RyR to their respective membrane is independent of each other $[18,99]$. This suggests that the T-tubule and SR separately posses the potential for self-assembly.

\section{Conclusion}

Whether T-tubule origin is from an inward or outward movement of membranes has been debated for many decades. Some co-workers have suggested that caveolar 
invagination fuses with the internal membrane tubules and thus facilitates their connection to the surface [34]. However, increasing evidences support the hypothesis that $\mathrm{T}$-tubules are formed by surface membrane invaginations starting from caveolae $[17,18,37]$. During myofiber maturation, the $\mathrm{T}$-tubule network grows up to occupy the entire muscle fiber. It is likely that $\mathrm{T}$-tubule proliferation happens by two complementary mechanisms: 1) membrane invagination and tubulation, and 2) membrane addition (Figure 4). BIN1 is a promising candidate for the regulation of membrane tubulation at $\mathrm{T}$ tubules. Invagination of T-tubules may be triggered at the site of caveolae formation on the sarcolemma. It is also possible that the growth of T-tubules is ensured by new membranes derived from endosomes and/or caveolae. CAV3, DYSF and MTM1 may play a major role in the formation and remodeling of growing $\mathrm{T}$-tubules by regulating the incorporation of internal membranes and/ or the turnover of existing tubular membranes. On the SR side, mitsugumin and junctophilin proteins would be important for the positioning of junctional SR to the proximity of transversal tubules. Membrane invagination and tubulation might be more active during early stages of T-tubule biogenesis (i.e. during muscle differentiation or after muscle injury), and membrane addition may be the main mechanism for $\mathrm{T}$-tubule proliferation during postnatal muscle growth or maintenance.

It is likely that other proteins may have important roles in these processes, like triadin $[19,101,102]$, a protein located on the SR, or telethonin (TCAP)) a large protein implicated in sarcomere assembly and recently suggested to play a role in T-tubule biogenesis [103], although their direct impact in triad biogenesis in skeletal muscle remains to be confirmed. There is still a lot

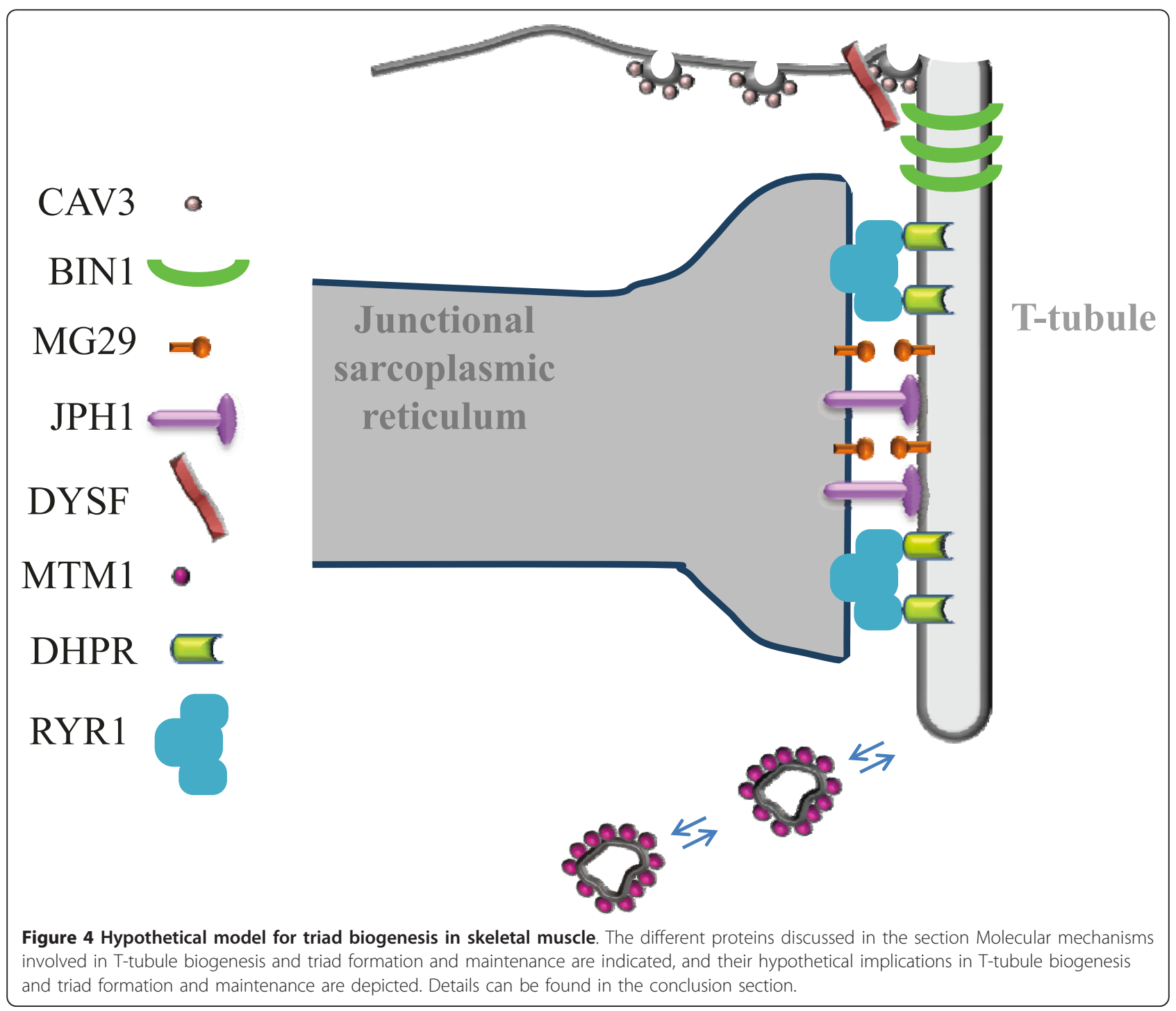


to learn about other potential proteins involved in triad biogenesis and to understand their biological role in muscle development.

\section{Acknowledgements}

This work was supported by grants from the Institut National de la Santé et de la Recherche Médicale (INSERM), the Centre National de la Recherche Scientifique (CNRS), University of Strasbourg (UdS), Collège de France and the Association Française contre les Myopathies (AFM). L. Al-Qusairi was supported by a fellowship from Fondation pour la Recherche Médicale (FRM).

\section{Author details}

'Department of Translational Medecine and Neurogenetics, IGBMC (Institut de Génétique et de Biologie Moléculaire et Cellulaire), 1 rue Laurent Fries, 67404 Illkirch, France. ${ }^{2}$ Inserm, U964, Illkirch, 1 rue Laurent Fries, 67404. France. ${ }^{3} \mathrm{CNRS}$, UMR7104, 1 rue Laurent Fries, 67404, IIlkirch, France. ${ }^{4}$ Université de Strasbourg, 1 rue Laurent Fries, 67404, IIlkirch, France. ${ }^{5}$ Collège de France, chaire de génétique humaine, 1 rue Laurent Fries, 67404 IIlkirch, France. ${ }^{6}$ Département de Pharmacologie \& Toxicologie, Université de Lausanne, 27 rue du Bugnon, 1005 Lausanne, Switzerland.

\section{Authors' contributions}

$L A Q$ and $J L$ conceived and drafted the manuscript.

\section{Competing interests}

The authors declare that they have no competing interests.

Received: 2 March 2011 Accepted: 13 July 2011 Published: 13 July 2011

\section{References}

1. Curtis BM, Catterall WA: Purification of the calcium antagonist receptor of the voltage-sensitive calcium channel from skeletal muscle transverse tubules. Biochemistry 1984, 23:2113-2118.

2. Fosset M, Jaimovich E, Delpont E, Lazdunski M: [3H]nitrendipine receptors in skeletal muscle. J Biol Chem 1983, 258:6086-6092.

3. Inui $\mathrm{M}$, Saito $\mathrm{A}$, Fleischer $\mathrm{S}$ : Isolation of the ryanodine receptor from cardiac sarcoplasmic reticulum and identity with the feet structures. J Biol Chem 1987, 262:15637-15642.

4. MacLennan DH, Wong PT: Isolation of a calcium-sequestering protein from sarcoplasmic reticulum. Proc Natl Acad Sci USA 1971, 68:1231-1235.

5. Chen SR, Zhang L, MacLennan DH: Asymmetrical blockade of the Ca2+ release channel (ryanodine receptor) by $12-\mathrm{kDa}$ FK506 binding protein. Proc Natl Acad Sci USA 1994, 91:11953-11957.

6. Tripathy A, Xu L, Mann G, Meissner G: Calmodulin activation and inhibition of skeletal muscle $\mathrm{Ca} 2+$ release channel (ryanodine receptor). Biophys J 1995, 69:106-119.

7. MacLennan DH, Brandl CJ, Korczak B, Green NM: Amino-acid sequence of a Ca2+ + Mg2+-dependent ATPase from rabbit muscle sarcoplasmic reticulum, deduced from its complementary DNA sequence. Nature 1985, 316:696-700

8. Fill M, Copello JA: Ryanodine receptor calcium release channels. Physiol Rev 2002, 82:893-922.

9. Krolenko SA, Amos WB, Brown SC, Tarunina MV, Lucy JA: Accessibility of Ttubule vacuoles to extracellular dextran and DNA: mechanism and potential application of vacuolation. J Muscle Res Cell Motil 1998, 19:603-611.

10. Krolenko SA, Lucy JA: Reversible vacuolation of T-tubules in skeletal muscle: mechanisms and implications for cell biology. Int Rev Cytol 2001, 202:243-298

11. Krolenko SA, Adamian S: [Stereologic analysis of vacuolization of the Tsystem of frog muscle fibers, detected using confocal fluorescence microscopy]. Tsitologiia 2000, 42:1125-1133.

12. Krolenko SA, Lucy JA: Vacuolation in T-tubules as a model for tubularvesicular transformations in biomembrane systems. Cell Biol Int 2002, 26:893-904.

13. Lannergren J, Bruton JD, Westerblad H: Vacuole formation in fatigued single muscle fibres from frog and mouse. J Muscle Res Cell Motil 1999, 20:19-32.
14. Kilarski W, Jakubowska M: An electron microscope study of myofibril formation in embryonic rabbit skeletal muscle. Z Mikrosk Anat Forsch 1979, 93:1159-1181.

15. Luff AR, Atwood $\mathrm{HL}$ : Changes in the sarcoplasmic reticulum and transverse tubular system of fast and slow skeletal muscles of the mouse during postnatal development. J Cell Biol 1971, 51:369-383.

16. Rossi D, Barone V, Giacomello E, Cusimano V, Sorrentino V: The sarcoplasmic reticulum: an organized patchwork of specialized domains. Traffic 2008, 9:1044-1049.

17. Takekura H, Flucher BE, Franzini-Armstrong C: Sequential docking, molecular differentiation, and positioning of T-Tubule/SR junctions in developing mouse skeletal muscle. Dev Biol 2001, 239:204-214.

18. Flucher BE, Takekura H, Franzini-Armstrong C: Development of the excitation-contraction coupling apparatus in skeletal muscle: association of sarcoplasmic reticulum and transverse tubules with myofibrils. Dev Biol 1993, 160:135-147.

19. Cusimano V, Pampinella F, Giacomello E, Sorrentino V: Assembly and dynamics of proteins of the longitudinal and junctional sarcoplasmic reticulum in skeletal muscle cells. Proc Natl Acad Sci USA 2009, 106:4695-4700

20. Franzini-Armstrong C: Simultaneous maturation of transverse tubules and sarcoplasmic reticulum during muscle differentiation in the mouse. Dev Biol 1991, 146:353-363.

21. Lisanti MP, Scherer PE, Tang Z, Sargiacomo M: Caveolae, caveolin and caveolin-rich membrane domains: a signalling hypothesis. Trends Cell Biol 1994, 4:231-235.

22. Smart EJ, Graf GA, McNiven MA, Sessa WC, Engelman JA, Scherer PE, Okamoto T, Lisanti MP: Caveolins, liquid-ordered domains, and signal transduction. Mol Cell Biol 1999, 19:7289-7304

23. Scherer PE, Okamoto T, Chun M, Nishimoto I, Lodish HF, Lisanti MP: Identification, sequence, and expression of caveolin-2 defines a caveolin gene family. Proc Natl Acad Sci USA 1996, 93:131-135.

24. Tang Z, Scherer PE, Okamoto T, Song K, Chu C, Kohtz DS, Nishimoto I, Lodish HF, Lisanti MP: Molecular cloning of caveolin-3, a novel member of the caveolin gene family expressed predominantly in muscle. J Biol Chem 1996, 271:2255-2261.

25. Song KS, Li S, Okamoto T, Quilliam LA, Sargiacomo M, Lisanti MP: Copurification and direct interaction of Ras with caveolin, an integral membrane protein of caveolae microdomains. Detergent-free purification of caveolae microdomains. J Biol Chem 1996, 271:9690-9697.

26. Parton RG, Way M, Zorzi N, Stang E: Caveolin-3 associates with developing T-tubules during muscle differentiation. J Cell Biol 1997, 136:137-154

27. Minetti C, Sotgia F, Bruno C, Scartezzini P, Broda P, Bado M, Masetti E, Mazzocco M, Egeo A, Donati MA, et al: Mutations in the caveolin-3 gene cause autosomal dominant limb-girdle muscular dystrophy. Nat Genet $1998,18: 365-368$

28. Betz RC, Schoser BG, Kasper D, Ricker K, Ramirez A, Stein V, Torbergsen T, Lee YA, Nothen MM, Wienker TF, et al: Mutations in CAV3 cause mechanical hyperirritability of skeletal muscle in rippling muscle disease. Nat Genet 2001, 28:218-219.

29. Hayashi T, Arimura T, Ueda K, Shibata H, Hohda S, Takahashi M, Hori H, Koga $\mathrm{Y}, \mathrm{Oka} \mathrm{N}$, Imaizumi T, et al: Identification and functional analysis of a caveolin-3 mutation associated with familial hypertrophic cardiomyopathy. Biochem Biophys Res Commun 2004, 313:178-184.

30. Vatta M, Ackerman MJ, Ye B, Makielski JC, Ughanze EE, Taylor EW, Tester DJ, Balijepalli RC, Foell JD, Li Z, et al: Mutant caveolin-3 induces persistent late sodium current and is associated with long-QT syndrome. Circulation 2006, 114.2104-2112.

31. Vaghy PL, Fang J, Wu W, Vaghy LP: Increased caveolin-3 levels in $\mathrm{mdx}$ mouse muscles. FEBS Lett 1998, 431:125-127.

32. Galbiati F, Engelman JA, Volonte D, Zhang XL, Minetti C, Li M, Hou H Jr, Kneitz B, Edelmann W, Lisanti MP: Caveolin-3 null mice show a loss of caveolae, changes in the microdomain distribution of the dystrophinglycoprotein complex, and t-tubule abnormalities. J Biol Chem 2001, 276:21425-21433.

33. Galbiati F, Volonte D, Chu JB, Li M, Fine SW, Fu M, Bermudez J, Pedemonte M, Weidenheim KM, Pestell RG, et al: Transgenic overexpression of caveolin-3 in skeletal muscle fibers induces a Duchenne-like muscular dystrophy phenotype. Proc Natl Acad Sci USA 2000, 97:9689-9694. 
34. Carozzi AJ, Ikonen E, Lindsay MR, Parton RG: Role of cholesterol in developing T-tubules: analogous mechanisms for T-tubule and caveolae biogenesis. Traffic 2000, 1:326-341.

35. Rosemblatt M, Hidalgo C, Vergara C, Ikemoto N: Immunological and biochemical properties of transverse tubule membranes isolated from rabbit skeletal muscle. J Biol Chem 1981, 256:8140-8148.

36. Nicot AS, Toussaint A, Tosch V, Kretz C, Wallgren-Pettersson C, Iwarsson E, Kingston H, Garnier JM, Biancalana V, Oldfors A, et al: Mutations in amphiphysin 2 (BIN1) disrupt interaction with dynamin 2 and cause autosomal recessive centronuclear myopathy. Nat Genet 2007, 39:1134-1139.

37. Lee E, Marcucci M, Daniell L, Pypaert M, Weisz OA, Ochoa GC, Farsad K, Wenk MR, De Camilli P: Amphiphysin 2 (Bin1) and T-tubule biogenesis in muscle. Science 2002, 297:1193-1196.

38. Ramjaun AR, MCPherson PS: Multiple amphiphysin II splice variants display differential clathrin binding: identification of two distinct clathrin-binding sites. J Neurochem 1998, 70:2369-2376.

39. Wechsler-Reya RJ, Elliott KJ, Prendergast GC: A role for the putative tumor suppressor Bin1 in muscle cell differentiation. Mol Cell Biol 1998, 18:566-575.

40. Bitoun M, Maugenre $S$, Jeannet PY, Lacene E, Ferrer $X$, Laforet $P$, Martin JJ, Laporte J, Lochmuller $\mathrm{H}$, Beggs $\mathrm{AH}$, et al: Mutations in dynamin 2 cause dominant centronuclear myopathy. Nat Genet 2005, 37:1207-1209.

41. Takei K, Slepnev VI, Haucke V, De Camilli P: Functional partnership between amphiphysin and dynamin in clathrin-mediated endocytosis. Nat Cell Biol 1999, 1:33-39.

42. Kojima C, Hashimoto A, Yabuta I, Hirose M, Hashimoto S, Kanaho Y, Sumimoto H, Ikegami T, Sabe H: Regulation of Bin1 SH3 domain binding by phosphoinositides. EMBO J 2004, 23:4413-4422.

43. Razzaq A, Robinson IM, McMahon HT, Skepper JN, Su Y, Zelhof AC, Jackson AP, Gay NJ, O'Kane CJ: Amphiphysin is necessary for organization of the excitation-contraction coupling machinery of muscles, but not for synaptic vesicle endocytosis in Drosophila. Genes Dev 2001, 15:2967-2979.

44. Toussaint A, Cowling BS, Hnia K, Mohr M, Oldfors A, Schwab Y, Yis U, Maisonobe T, Stojkovic T, Wallgren-Pettersson C, et al: Defects in amphiphysin 2 (BIN1) and triads in several forms of centronuclear myopathies. Acta Neuropathol 2011, 121:253-266.

45. Muller AJ, Baker JF, DuHadaway JB, Ge K, Farmer G, Donover PS, Meade R, Reid C, Grzanna R, Roach AH, et al: Targeted disruption of the murine Bin1/Amphiphysin II gene does not disable endocytosis but results in embryonic cardiomyopathy with aberrant myofibril formation. Mol Cell Biol 2003, 23:4295-4306.

46. Bashir R, Britton S, Strachan T, Keers S, Vafiadaki E, Lako M, Richard I, Marchand S, Bourg N, Argov Z, et al: A gene related to Caenorhabditis elegans spermatogenesis factor fer- 1 is mutated in limb-girdle muscular dystrophy type 2B. Nat Genet 1998, 20:37-42.

47. Liu J, Aoki M, Illa I, Wu C, Fardeau M, Angelini C, Serrano C, Urtizberea JA, Hentati F, Hamida MB, et al: Dysferlin, a novel skeletal muscle gene, is mutated in Miyoshi myopathy and limb girdle muscular dystrophy. Nat Genet 1998, 20:31-36.

48. Illa I, Serrano-Munuera C, Gallardo E, Lasa A, Rojas-Garcia R, Palmer J, Gallano P, Baiget M, Matsuda C, Brown RH: Distal anterior compartment myopathy: a dysferlin mutation causing a new muscular dystrophy phenotype. Ann Neurol 2001, 49:130-134.

49. Bansal D, Miyake K, Vogel SS, Groh S, Chen CC, Williamson R, McNeil PL, Campbell KP: Defective membrane repair in dysferlin-deficient muscular dystrophy. Nature 2003, 423:168-172.

50. Klinge L, Laval S, Keers S, Haldane F, Straub V, Barresi R, Bushby K: From Ttubule to sarcolemma: damage-induced dysferlin translocation in early myogenesis. FASEB J 2007, 21:1768-1776.

51. Klinge L, Harris J, Sewry C, Charlton R, Anderson L, Laval S, Chiu YH, Hornsey M, Straub V, Barresi R, et al: Dysferlin associates with the developing T-tubule system in rodent and human skeletal muscle. Muscle Nerve 2010, 41:166-173.

52. Bittner RE, Anderson LV, Burkhardt E, Bashir R, Vafiadaki E, Ivanova S, Raffelsberger T, Maerk I, Hoger H, Jung M, et al: Dysferlin deletion in SJL mice (SJL-Dysf) defines a natural model for limb girdle muscular dystrophy 2B. Nat Genet 1999, 23:141-142.

53. Glover LE, Newton K, Krishnan G, Bronson R, Boyle A, Krivickas LS, Brown RH $\mathrm{Jr}$ : Dysferlin overexpression in skeletal muscle produces a progressive myopathy. Ann Neurol 2010, 67:384-393.
54. Han R, Bansal D, Miyake K, Muniz VP, Weiss RM, McNeil PL, Campbell KP. Dysferlin-mediated membrane repair protects the heart from stressinduced left ventricular injury. J Clin Invest 2007, 117:1805-1813.

55. Ho M, Post CM, Donahue LR, Lidov HG, Bronson RT, Goolsby H, Watkins SC, Cox GA, Brown RH Jr: Disruption of muscle membrane and phenotype divergence in two novel mouse models of dysferlin deficiency. Hum Mol Genet 2004, 13:1999-2010.

56. Ampong BN, Imamura M, Matsumiya T, Yoshida M, Takeda S: Intracellular localization of dysferlin and its association with the dihydropyridine receptor. Acta Myol 2005, 24:134-144.

57. Hernandez-Deviez DJ, Martin S, Laval SH, Lo HP, Cooper ST, North KN, Bushby K, Parton RG: Aberrant dysferlin trafficking in cells lacking caveolin or expressing dystrophy mutants of caveolin-3. Hum Mol Genet 2006, 15:129-142.

58. Selcen D, Stilling G, Engel AG: The earliest pathologic alterations in dysferlinopathy. Neurology 2001, 56:1472-1481.

59. Komazaki S, Nishi M, Kangawa K, Takeshima H: Immunolocalization of mitsugumin29 in developing skeletal muscle and effects of the protein expressed in amphibian embryonic cells. Dev Dyn 1999, 215:87-95.

60. Komazaki S, Nishi M, Takeshima H, Nakamura H: Abnormal formation of sarcoplasmic reticulum networks and triads during early development of skeletal muscle cells in mitsugumin29-deficient mice. Dev Growth Differ 2001, 43:717-723.

61. Nishi M, Komazaki S, Kurebayashi N, Ogawa Y, Noda T, lino M, Takeshima H: Abnormal features in skeletal muscle from mice lacking mitsugumin29. $J$ Cell Biol 1999, 147:1473-1480.

62. Brotto MA, Nagaraj RY, Brotto LS, Takeshima H, Ma JJ, Nosek TM: Defective maintenance of intracellular Ca2+ homeostasis is linked to increased muscle fatigability in the MG29 null mice. Cell Res 2004, 14:373-378.

63. Pan Z, Yang D, Nagaraj RY, Nosek TA, Nishi M, Takeshima H, Cheng H, Ma J: Dysfunction of store-operated calcium channel in muscle cells lacking mg29. Nat Cell Biol 2002, 4:379-383.

64. Cai C, Masumiya H, Weisleder N, Matsuda N, Nishi M, Hwang M, Ko JK, Lin P, Thornton A, Zhao X, et al: MG53 nucleates assembly of cell membrane repair machinery. Nat Cell Biol 2009, 11:56-64.

65. Wang X, Xie W, Zhang Y, Lin P, Han L, Han P, Wang Y, Chen Z, Ji G Zheng $M$, et al: Cardioprotection of ischemia/reperfusion injury by cholesterol-dependent MG53-mediated membrane repair. Circ Res 2010, 107:76-83.

66. Cai C, Weisleder N, Ko JK, Komazaki S, Sunada Y, Nishi M, Takeshima H, Ma J: Membrane repair defects in muscular dystrophy are linked to altered interaction between MG53, caveolin-3, and dysferlin. J Biol Chem 2009, 284:15894-15902

67. Takeshima H, Komazaki S, Nishi M, lino M, Kangawa K: Junctophilins: a novel family of junctional membrane complex proteins. Mol Cell 2000, 6:11-22.

68. Minamisawa S, Oshikawa J, Takeshima H, Hoshijima M, Wang Y, Chien KR, Ishikawa Y, Matsuoka R: Junctophilin type 2 is associated with caveolin-3 and is down-regulated in the hypertrophic and dilated cardiomyopathies. Biochem Biophys Res Commun 2004, 325:852-856.

69. Wei S, Guo A, Chen B, Kutschke W, Xie YP, Zimmerman K, Weiss RM, Anderson ME, Cheng $\mathrm{H}$, Song LS: T-tubule remodeling during transition from hypertrophy to heart failure. Circ Res 2010, 107:520-531.

70. Holmes SE, O'Hearn E, Rosenblatt A, Callahan C, Hwang HS, IngersollAshworth RG, Fleisher A, Stevanin G, Brice A, Potter NT, et al: A repeat expansion in the gene encoding junctophilin-3 is associated with Huntington disease-like 2. Nat Genet 2001, 29:377-378.

71. Nishi M, Sakagami H, Komazaki S, Kondo H, Takeshima H: Coexpression of junctophilin type 3 and type 4 in brain. Brain Res Mol Brain Res 2003, 118:102-110

72. Ito K, Komazaki S, Sasamoto K, Yoshida M, Nishi M, Kitamura K, Takeshima $\mathrm{H}$ : Deficiency of triad junction and contraction in mutant skeletal muscle lacking junctophilin type 1. J Cell Biol 2001, 154:1059-1067

73. Komazaki S, Ito K, Takeshima H, Nakamura H: Deficiency of triad formation in developing skeletal muscle cells lacking junctophilin type 1. FEBS Lett 2002, 524:225-229.

74. Laporte J, Bedez F, Bolino A, Mandel JL: Myotubularins, a large diseaseassociated family of cooperating catalytically active and inactive phosphoinositides phosphatases. Hum Mol Genet 2003, 12(Spec No 2): R285-292. 
75. Laporte J, Hu L, Kretz C, Mandel JL, Kioschis P, Coy JF, Klauck SM, Poustka A, Dahl N: A gene mutated in X-linked myotubular myopathy defines a new putative tyrosine phosphatase family conserved in yeast. Nat Genet 1996, 13:175-182.

76. Blondeau F, Laporte J, Bodin S, Superti-Furga G, Payrastre B, Mandel JL: Myotubularin, a phosphatase deficient in myotubular myopathy, acts on phosphatidylinositol 3-kinase and phosphatidylinositol 3-phosphate pathway. Hum Mol Genet 2000, 9:2223-2229.

77. Schaletzky J, Dove SK, Short B, Lorenzo O, Clague MJ, Barr FA: Phosphatidylinositol-5-phosphate activation and conserved substrate specificity of the myotubularin phosphatidylinositol 3-phosphatases. Curr Biol 2003, 13:504-509.

78. Taylor GS, Maehama T, Dixon JE: Myotubularin, a protein tyrosine phosphatase mutated in myotubular myopathy, dephosphorylates the lipid second messenger, phosphatidylinositol 3-phosphate. Proc Natl Acad Sci USA 2000, 97:8910-8915.

79. Tronchere H, Laporte J, Pendaries C, Chaussade C, Liaubet L, Pirola L, Mandel JL, Payrastre B: Production of phosphatidylinositol 5-phosphate by the phosphoinositide 3-phosphatase myotubularin in mammalian cells. J Biol Chem 2004, 279:7304-7312.

80. Buj-Bello A, Fougerousse F, Schwab Y, Messaddeq N, Spehner D, Pierson CR, Durand M, Kretz C, Danos O, Douar AM, et al: AAV-mediated intramuscular delivery of myotubularin corrects the myotubular myopathy phenotype in targeted murine muscle and suggests a function in plasma membrane homeostasis. Hum Mol Genet 2008 17:2132-2143.

81. Buj-Bello A, Laugel V, Messaddeq N, Zahreddine H, Laporte J, Pellissier JF, Mandel JL: The lipid phosphatase myotubularin is essential for skeletal muscle maintenance but not for myogenesis in mice. Proc Natl Acad Sci USA 2002, 99:15060-15065

82. Al-Qusairi L, Weiss N, Toussaint A, Berbey C, Messaddeg N, Kretz C, Sanoudou D, Beggs AH, Allard B, Mandel $J$, et al: T-tubule disorganization and defective excitation-contraction coupling in muscle fibers lacking myotubularin lipid phosphatase. Proc Natl Acad Sci USA 2009, 106:18763-18768.

83. Dowling JJ, Vreede AP, Low SE, Gibbs EM, Kuwada JY, Bonnemann CG, Feldman EL: Loss of myotubularin function results in T-tubule disorganization in zebrafish and human myotubular myopathy. PLOS Genet 2009, 5:e1000372.

84. Ribeiro I, Yuan L, Tanentzapf G, Dowling JJ, Kiger A: Phosphoinositide regulation of integrin trafficking required for muscle attachment and maintenance. PLoS Genet 2011, 7:e1001295.

85. Fujii J, Otsu K, Zorzato F, de Leon S, Khanna VK, Weiler JE, O'Brien PJ, MacLennan $\mathrm{DH}$ : Identification of a mutation in porcine ryanodine receptor associated with malignant hyperthermia. Science 1991 253:448-451.

86. Otsu K, Khanna VK, Archibald AL, MacLennan DH: Cosegregation of porcine malignant hyperthermia and a probable causal mutation in the skeletal muscle ryanodine receptor gene in backcross families. Genomics 1991, 11:744-750.

87. Quane KA, Healy JM, Keating KE, Manning BM, Couch FJ, Palmucci LM, Doriguzzi C, Fagerlund TH, Berg K, Ording $H$, et al: Mutations in the ryanodine receptor gene in central core disease and malignant hyperthermia. Nat Genet 1993, 5:51-55.

88. Zhang Y, Chen HS, Khanna VK, De Leon S, Phillips MS, Schappert K, Britt BA Browell AK, MacLennan DH: A mutation in the human ryanodine receptor gene associated with central core disease. Nat Genet 1993, 5:46-50.

89. Monnier N, Ferreiro A, Marty I, Labarre-Vila A, Mezin P, Lunardi J: A homozygous splicing mutation causing a depletion of skeletal muscle RYR1 is associated with multi-minicore disease congenital myopathy with ophthalmoplegia. Hum Mol Genet 2003, 12:1171-1178.

90. Clarke NF, Waddell LB, Cooper ST, Perry M, Smith RL, Kornberg AJ, Muntoni F, Lillis S, Straub V, Bushby K, et al: Recessive mutations in RYR1 are a common cause of congenital fiber type disproportion. Hum Mutat 2010, 31:E1544-1550

91. Sato I, Wu S, Ibarra MC, Hayashi YK, Fujita H, Tojo M, Oh SJ, Nonaka I, Noguchi S, Nishino I: Congenital neuromuscular disease with uniform type 1 fiber and RYR1 mutation. Neurology 2008, 70:114-122.

92. Bevilacqua JA, Monnier N, Bitoun M, Eymard B, Ferreiro A, Monges S, Lubieniecki F, Taratuto AL, Laquerriere A, Claeys KG, et al: Recessive RYR1 mutations cause unusual congenital myopathy with prominent nuclear internalization and large areas of myofibrillar disorganization. Neuropathol Appl Neurobiol 2011, 37:271-284.

93. Wilmshurst JM, Lillis S, Zhou H, Pillay K, Henderson H, Kress W, Muller CR, Ndondo A, Cloke V, Cullup T, et al: RYR1 mutations are a common cause of congenital myopathies with central nuclei. Ann Neurol 2010, 68:717-726.

94. Yuan $\mathrm{SH}$, Arnold W, Jorgensen AO: Biogenesis of transverse tubules and triads: immunolocalization of the 1,4-dihydropyridine receptor, TS28, and the ryanodine receptor in rabbit skeletal muscle developing in situ. J Cell Biol 1991, 112:289-301.

95. Chaudhari N: A single nucleotide deletion in the skeletal muscle-specific calcium channel transcript of muscular dysgenesis (mdg) mice. J Biol Chem 1992, 267:25636-25639.

96. Felder E, Protasi F, Hirsch R, Franzini-Armstrong C, Allen PD: Morphology and molecular composition of sarcoplasmic reticulum surface junctions in the absence of DHPR and RyR in mouse skeletal muscle. Biophys $J$ 2002, 82:3144-3149.

97. Franzini-Armstrong C, Pincon-Raymond M, Rieger F: Muscle fibers from dysgenic mouse in vivo lack a surface component of peripheral couplings. Dev Biol 1991, 146:364-376.

98. Powell JA, Petherbridge L, Flucher BE: Formation of triads without the dihydropyridine receptor alpha subunits in cell lines from dysgenic skeletal muscle. J Cell Biol 1996, 134:375-387.

99. Takekura H, Franzini-Armstrong C: Correct targeting of dihydropyridine receptors and triadin in dyspedic mouse skeletal muscle in vivo. Dev Dyn 1999, 214:372-380.

100. Knudson CM, Chaudhari N, Sharp AH, Powell JA, Beam KG, Campbell KP: Specific absence of the alpha 1 subunit of the dihydropyridine receptor in mice with muscular dysgenesis. J Biol Chem 1989, 264:1345-1348.

101. Marty I, Faure J, Fourest-Lieuvin A, Vassilopoulos S, Oddoux S, Brocard J: Triadin: what possible function 20 years later? J Physio/ 2009, 587:3117-3121.

102. Shen $X$, Franzini-Armstrong $C$, Lopez JR, Jones LR, Kobayashi YM, Wang $Y$, Kerrick WG, Caswell AH, Potter JD, Miller T, et al: Triadins modulate intracellular $\mathrm{Ca}(2+)$ homeostasis but are not essential for excitationcontraction coupling in skeletal muscle. J Biol Chem 2007 282:37864-37874

103. Zhang R, Yang J, Zhu J, Xu X: Depletion of zebrafish Tcap leads to muscular dystrophy via disrupting sarcomere-membrane interaction, not sarcomere assembly. Hum Mol Genet 2009, 18:4130-4140.

104. Marieb NElaine: Human Anatomy and Physiology. 7 edition. Pearson Education, Inc.; 2007

doi:10.1186/2044-5040-1-26

Cite this article as: Al-Qusairi and Laporte: T-tubule biogenesis and triad formation in skeletal muscle and implication in human diseases. Skeletal Muscle 2011 1:26

\section{Submit your next manuscript to BioMed Central and take full advantage of:}

- Convenient online submission

- Thorough peer review

- No space constraints or color figure charges

- Immediate publication on acceptance

- Inclusion in PubMed, CAS, Scopus and Google Scholar

- Research which is freely available for redistribution

Submit your manuscript at www.biomedcentral.com/submit
C Biomed Central 